Themenheft: Parting of the Ways. Die Trennung der Wege von Juden und Christen in der neueren Forschung

Zu diesem Heft . . . . . . . . . . . . . . . . . . . . 403

\title{
Hauptartikel
}

Angela Standhartinger

»Parting of the Ways". Stationen einer Debatte . . . . . . . . . . . . . 406

Manuel Vogel

Jüdisch versus christlich? "Parting of the ways « als Problem der Terminologie

in Quellen- und Beschreibungssprache . . . . . . . . . . . . . . 418

Udo Schnelle

Römische Religionspolitik und die getrennten Wege von Juden und Christen . 432

Tobias Nicklas

Diversität, Dynamik und Differenzierung. Eine Diskussion mit Udo Schnelles

Modell der "getrennten Wege von Römern, Juden und Christen« . . . . . . . 444

Kathy Ehrensperger

Die $>$ Paul within Judaism«-Perspektive. Eine Übersicht. . . . . . . . . . . . . 455

Adele Reinhartz

The Gospel of John and the »Parting of the Ways« . . . . . . . . . . . 465

\section{Kritisches Forum}

Markus Öbler

Michael Wolter, Der Brief an die Römer ． . . . . . . . . . . . . . . 472 